Revista Iberoamericana, Vol. LXX, Núm. 206, Enero-Marzo 2004, 159-182

\title{
LA AGUJA SUBVERSIVA: EL DES-BORDE DE LA CIUDAD LETRADA
}

POR

\author{
Beatriz GonzÁlez Stephan \\ Rice University
}

\section{LA AGUJA QUE CUENTA CUENTOS}

El arte del tejido le permite a la protagonista sin nombre de "Soledad de Sangre" hacerse de un pequeño capital con el que, aparte de sufragar con regularidad los gastos de la economía doméstica, puede adquirir un viejo fonógrafo con el cual llenar de música sus horas vacías. El negocio del tejido, si bien no le da la independencia para deshacerse de un marido que la explota y maltrata, sí le concede la posibilidad de tener un espacio propio para su recreación. Son momentos no sólo de intimidad del personaje, sino también de una autorrealización contemplativa donde el arte le ayuda a evadirse de una realidad poco amable. La correlación entre las destrezas laborales de la aguja e hilo y el consumo del arte son notorias.

Marta Brunet en este relato coloca el trabajo del tejido y el arte de la música en una relación que condensa problemáticas histórico-culturales que han distribuido y discriminado sexuadamente las prácticas artísticas en altas y bajas, en arte y artesanía, en objetos de valor de uso y otros con valor simbólico. La competencia que tiene la mujer en el tejido -llega a tener muchos clientes que le hacen encargos- le permite manejar con solvencia la economía de la casa; no es un arte; sin embargo, es un saber que la convierte en un sujeto productivo. De allí que el marido la valore como un bien que le procura objetos materiales.

Saber tejer es una destreza cuyo aprendizaje se adquiere a través de largas tradiciones informales, pero sirve en el intercambio mercantil para arreglar la casa, comprar cosas, entre ellas, el fonógrafo; el arte lo producen otros, los músicos, y a la mujer tejedora sólo le es dado escucharlo. Ella cargada con el peso de la materialidad de su cuerpo laboral se resuelve en mercancía, y su relación con el arte es sólo pasiva. Las ganancias de su “artesanía” le permiten disfrutar del arte, no producirlo. La distinción entre tejido -como trabajo, artesanía, femenino, y realidad-y música -como ocio, arte, masculino, y evasión-condensa una tensión que se perfila en las últimas décadas del siglo XIX, y que este relato ya del $\mathrm{xx}$ recoge con la transparencia de presupuestos de una discriminación que no alcanza a resolver.

En todo caso, interesa retener una ecuación que ha funcionado como eje vertebrador de las prácticas culturales, en la cual a la mujer se le han destinado las artes menores o artesanías -los textiles, el bordado, la costura, la alfarería, la cocina-, y a los hombres lo 
que se reconoce socialmente como las artes mayores -la pintura, escultura, arquitectura, música-: es decir, concomitantemente, una distribución sexuada de materiales, técnicas, destrezas, lugares de adquisición de saberes, conjuntamente con la separación de los espacios públicos y privados. No en vano, la protagonista de “Soledad de Sangre” fabrica sus tejidos en la casa, y sale a la calle a comprar el fonógrafo. Irónicamente, también vale reparar en el detalle que lo que se produce en el núcleo familiar se inserta productivamente en el espacio público; y el arte que circula en el mercado altera y contamina la ficticia inviolabilidad del hogar.

El desplazamiento de las artes del tejido al traspatio de los quehaceres culturales no siempre acogió cómoda y complacientemente esta locación obliterada. Sin embargo, por otra parte, también es cierto que la expresión de esta incomodidad histórica -porque hubo un tiempo en que tapices, pasamanerías y bordados eran saberes altamente apreciados-no se dio con suficiente transparencia crítica: la mujer bordaba y tejía sin asumida competencia con las artes mayores; pero de algún modo lidiaba implícitamente con las categorías que permanentemente la excluían. Y desde luego, el reto mayor era entrar directamente a competir por la palabra escrita, el don de la letra impresa, a cambio del silencio que exigía la labor del tejido. Pero será desde el terreno de uno de los lenguajes más tradicionales, el hilo y la aguja, que hábilmente empezará a negociar espacios, límites, y agenciamientos que permitirán repensar su subjetividad moderna.

En 1883, la Venezuela de Antonio Guzmán Blanco (1870-1888) organizó su primera Exposición Nacional para conmemorar el Natalicio del Libertador Simón Bolívar. El acontecimiento remeció las bases aún provincianas de un país que apenas salía de las rémoras del pasado colonial, pero al tiempo con no pocas pretensiones de colocarse en el umbral del más sofisticado cosmopolitismo. La ocasión propició una encrucijada de eventos culturales nada despreciables, y que excedían, en mucho, al simple relato catalogador que hiciera su cronista oficial Adolfo Ernst. ${ }^{1}$ Pues bien, en una de las salas del Palacio de la Exposición, la desconocida señorita J. Paz Guevara-que prefirió casi al igual que la protagonista del relato de Marta Brunet ocultar su identidad- expuso un cuadro hecho a base de cabello humano, en el cual representaba a Policarpa Salavarrieta (17931817), heroína de los tiempos de la Independencia colombiana. Pero, ¿cómo reparar en este gesto, al tiempo tan delicado para con la mártir colombiana, pero también tan poco cónsono para el momento, donde todo debía aludir al Padre de la Patria, o al menos al Ilustre Americano que la regeneraba? Desde luego, nadie se detuvo en ella, y la obra fue desechada; era una de las tantas mujeres que se habían presentado en la Exposición con sus "labores de mano" y que concurría silenciosamente con un modesto retrato de una dama. Pero es de recalcar que fue el único retrato de una mujer hecho por otra, dentro de centenares de obras y objetos exhibidos allí también realizados por mujeres que mostraban sus habilidades no sólo en el tejido.

${ }^{1}$ Todas las Exposiciones Universales de la época fueron ampliamente reseñadas. Cada una podía disponer de su catálogo, que describía prolijamente los artículos allí presentados, así como los pabellones de los diversos países. El registro de la venezolana lo hizo el científico venezolano Adolfo Ernst en dos gruesos volúmenes, La Exposición Nacional de Venezuela en 1883, publicados un año después, en 1884. Fueron reeditados a propósito del segundo Centenario del Natalicio del Libertador, en Obras Completas de Adolfo Ernst en 1983. Citaremos de esta edición. 
Ante los ojos de la concurrencia masculina, J. Paz Guevara se esmeraba en llevar el arte del bordado en pelo al mismo nivel de la pintura al óleo; el género del retrato, profusamente cultivado por los pintores hombres, estaba muy en boga en aquellos días de fervoroso ascenso de una burguesía ávida por representarse y darse prestigio. Obviamente, los retratos hechos en materias perecederas -como el pelo, los hilos, plumas, y escamas de pescado- no podían satisfacer del todo la ilusión de eternidad de estos sectores.

El retrato allí de Policarpa Salavarrieta implicaba mucho sin decir nada. Por los momentos, nos vamos a quedar con algunas implicaciones: Policarpa se desempeñaba oficialmente como costurera; prestaba sus servicios a las damas de la nobleza virreinal colombiana. Cosía y bordaba. Pero también lidiaba en las huestes patrióticas por la independencia del país. Esta era su identidad clandestina. Como costurera, era inofensiva; como espía peligrosa; por ello fue fusilada. ¿Cuál de los dos rostros le interesaba a Paz Guevara? ¿La Policarpa que cosía en silencio en las casas, o la Policarpa comprometida con la causa política?

Todos los gestos y detalles de la Exposición Nacional, así como los no pocos años que la antecedieron y que marcaron el gobierno de Guzmán Blanco, giraron en torno a un profuso e hipertrofiado culto a Simón Bolívar. Padres y próceres abarrotaron el imaginario colectivo y llenaron la historia nacional de figuras masculinas. A estas alturas del siglo ya era difícil imaginar la participación de la mujer en la vida social por cuanto el tejido imaginario fue ocupado por el protagonismo de uno de los sexos. La hegemonía de las representaciones patriarcales la había borrado del mapa. Sin embargo, la presencia tal vez inquietante de Policarpa Salavarrieta en los pasillos de la Exposición era la punta del hilo de otra memoria. El contingente nada exiguo de mujeres venezolanas que asistió a la Exposición no celebró con sus ofrendas al Padre de la Patria. El rostro de Simón Bolívar estaba significativamente ausente de sus obras; en su lugar, emergía la imagen de Policarpa Salavarrieta.

No deja de haber algo de perturbador en el poder económico que puede generar el tejido en el espacio doméstico y la eventual independencia que podría ganar el personaje en "Soledad de Sangre"; y el poder del rostro bordado de Policarpa Salavarrieta en medio de las representaciones patriarcales de la nación: ambos casos centraban su atención en el sentido productivo-económico y simbólico-del lenguaje que escribe con hilos y agujas las claves secretas de la textura del tejido. ${ }^{2}$

\footnotetext{
${ }^{2}$ Véase al respecto el interesante libro de Rozsika Parker, The Subversive Stitch. Embroidery and the Making of the Femenine (1984). Examina la importancia central de identificar la construcción de la identidad femenina ligada al hogar con la labor de bordado, pasando a significar éste más que un arte, una habilidad, que cuanto más desarrollada definía la mayor virtud, castidad, pureza y obediencia del ideal femenino como esposa ejemplar. La cualidad "artística" se desplazaba del bordado a la estetización de la mujer. Ésta era en sí una pieza artística. Su mera presencia reemplazaba la obra de arte. De allí pensar que un ente artístico viviente se reproducía a sí mismo en arte era una redundancia. El duplicado no tenía sentido. El arte producido por las mujeres quedaba cancelado.
} 
Un Centenario para la Patria y para el Mundo

El 2 de agosto de 1883 se inauguró la primera Exposición Nacional de Venezuela y la tercera del continente latinoamericano ${ }^{3}$ para celebrar el Centenario del Natalicio del Libertador bajo los auspicios del “vigoroso y progresista gobierno del Ilustre Americano”, Antonio Guzmán Blanco. El antiguo recinto de la Universidad de Caracas, suntuosamente remodelado de acuerdo al más puro estilo neogótico - estilo acogido con preferencia en las Exposiciones de Inglaterra y que a la hora marcaba las pautas de la más avanzada modernidad arquitectónica-, recibió durante aquellos días 62.841 visitantes, de los cuales no pocos habían venido de lejanas latitudes para observar bajo los 14 reflectores de luz eléctrica no sólo los avances y progresos de esta zona tórrida, sino las incalculables promesas de las selvas tropicales. ${ }^{4}$

Todo se dispuso primorosamente a lo largo de las innumerables galerías al estilo pompeyano -también los tiempos revivían todos los estilos artísticos y el pastish era de buen gusto-; y si no fuera por un magnífico reloj ofrenda del gremio de joyeros de Caracas que marcaba todas las horas con las gloriosas notas del Himno Nacional, la distinguida concurrencia podía perfectamente haberse sentido trasladada al Palacio de Cristal en Londres, si además tenemos presente que entre el numeroso y bien acicalado público caraqueño se encontraba el Príncipe Henrique de Prusia y los Cónsules de Marruecos, Manaos, Bruselas y Hamburgo, que finalmente habían decidido honrar con su presencia la vanidad del Regenerador de la Patria.

Sin duda, la fecha del Centenario maquillaba la imagen del país tanto para el exterior -era imprescindible insertarse adecuadamente en las exigencias que demandaba el progreso noroccidental-, como también cristalizaba una autorepresentación para el consumo interno. Los esfuerzos del guzmanato habían efectivamente transformado la

\footnotetext{
${ }^{3}$ La primera Exposición latinoamericana se realizó en Santiago de Chile en 1875; la segunda en Buenos Aires en 1881; y la tercera en Caracas. Lo que indicaba que Antonio Guzmán Blanco quería situar rápidamente a Venezuela en la mira del mercado internacional. En el panorama mundial, Venezuela era la décima después de la gran Exposición Universal realizada en Londres en 1851. Había asistido a la fecha a unas cuantas: Londres (1862), París (1867), Viena (1873), Bremen (1874), Santiago de Chile (1875), Filadelfia (1876), París (1878) , y Buenos Aires (1881), lo que le permitió reconvertir esa experiencia cosmopolita en la aún provinciana capital de la República.

${ }^{4}$ Guzmán Blanco quería atraer el mundo entero hacia Venezuela, que de algún modo era la "entrada" a la América del Sur. Esto suponía inversiones extranjeras, intercambio de riquezas, y desde luego extracción a mansalva. Sin pretender agotar aquí la lista de consulados invitados a participar en la Exposición, fueron convocados los cónsules de Hamburgo, Berlín, Bremen, Lübeck, Strasburgo, Francfort, Leipzig, Viena, Trieste, Bruselas, Amberes, Río de Janeiro, Río Grande del Norte, San Luis, Santiago de Chile, Habana, Copenhagen, San Thomas, Nueva York, Boston, Filadelfia, Baltimore, Chicago, Bogotá, Barranquilla, Panamá, Veracruz, Tampico, Madrid, Barcelona, Málaga, Valencia, Bilbao, Tarragona, Niza, Argel, Cape Town, Kingston, Antiguas, Barbados, Gibraltar, Marruecos, Omoa, Salerno, Callao, Lima, Casa Blanca, San Petersburgo etc. etc. De los países extranjeros que enviaron delegaciones y productos, aparte de los Estados Unidos del Norte, fue Bélgica, que tuvo la deferencia de enviar obras de arte a la Exposición, incluso un retrato del General Guzmán Blanco hecho a plumilla por una pintora belga que también prefirió resguardar su identidad.
} 
imagen de un país en ruinas — - legado aún del terremoto de 1812—en al menos un país con ciertas zonas capitalinas que emulaban con sus edificios públicos, plazas, teatros, hipódromos, balnearios, ferrocarriles, tranvías y avenidas, los centros metropolitanos. En este renglón, el Palacio de la Exposición, con su "Santa Capilla" adosada a uno de sus costados, deseaba ser la extensión transplantada de Londres y París simultáneamente.

Trece años de intensas transformaciones urbanas, rediseño de edificios, remozamiento de plazas y avenidas, creación de nuevos espacios, modernización y saneamiento de infraestructuras, aparte de una implementación compulsiva y no menos calculada de ritos festivos en torno a fechas patrias siempre acompañadas de una profusión de gestos simbólicos histriónicos y monumentalistas, habían preparado la sensibilidad venezolana para este magno acontecimiento del Centenario, que condensaba largos años de una voluntad política encaminada a fortalecer el aparato estatal. ${ }^{5} 1883$ significó un momento

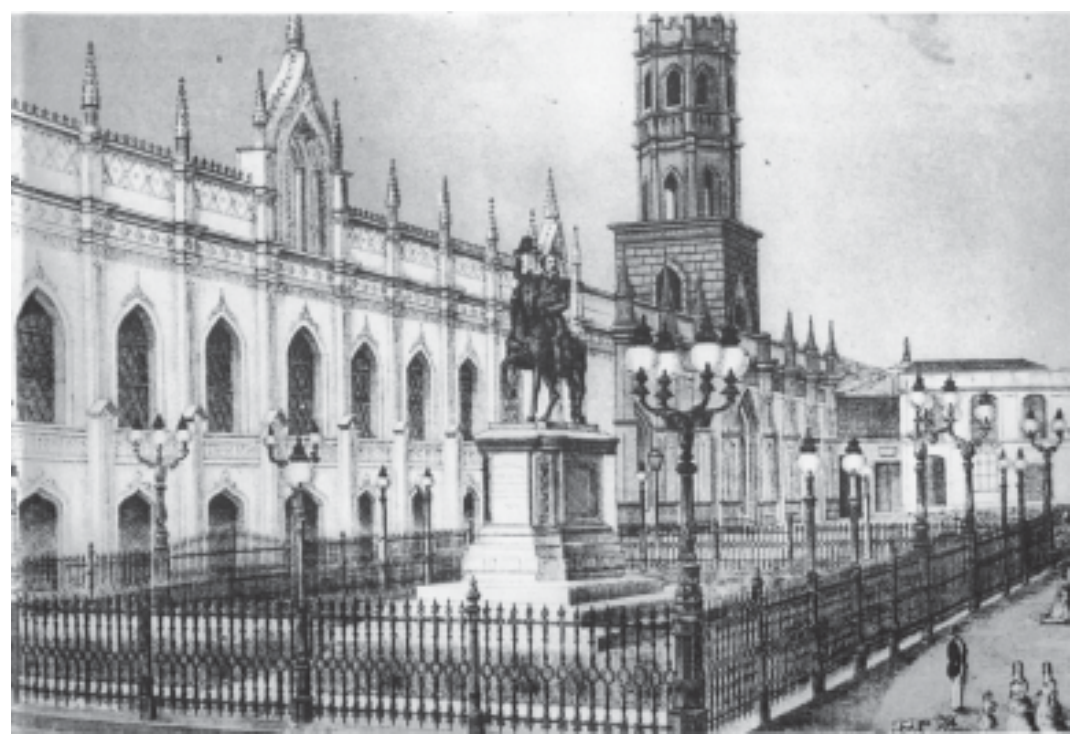

El guzmanato eligió para el Palacio de la Exposición Nacional el estilo neogótico. Se convertía así en la nueva catedral de los tiempos modernos que habrían de sacralizar las mercancías allí exhibidas. Aunque se conmemoraba el Centenario del Natalicio de Simón Bolívar (1883), la egolatría del Ilustre Americano no pudo resistir mandarse a hacer una estatua ecuestre cercada al estilo Napoleón III para agasajar la concurrencia que habría de asistir a la Exposición. No en balde fue llamada "El Saludante” (1975).

\footnotetext{
${ }^{5}$ Véase al respecto el interesante libro de Paulette Silva Beauregard, Una vasta morada de enmascarados (1993), que explica in extenso las prácticas culturales utilizadas por el gobierno guzmancista para apuntalar el aparato estatal, y la función sensiblemente política que tomaron todas las manifestaciones culturales para construir el imaginario de las tradiciones históricas necesarias para el Estado nacional moderno.
} 
de condensación de la autocracia guzmancista, que resumía, por un lado, la moderna consolidación del aparato estatal y una coherente articulación del imaginario verbosimbólico de la sociedad civil, y, por el otro, la capacidad de colocar en un gesto no menos exhibicionista todas las manifestaciones de las fuerzas vivas del país en la vitrina del mercado internacional.

Al término de casi dos décadas, el Estado nacional, bajo la égida de Guzmán Blanco, había capitalizado un patrimonio de obras edilicias y plásticas que sin duda habían ayudado enormemente con el poder visual de la imagen no sólo a consolidar su gestión política, sino a articular el imaginario de una sociedad hasta entonces fragmentada y dispersa; o al menos logró configurar una combinatoria nada despreciable entre la construcción de una poética del poder y las funciones estético-simbólicas de la política, que sirvieron oportunamente tanto a sus gestiones personalistas como a las administrativoestatales. Ya desde los inicios del régimen (1870) se promovieron formas banalizadas de la cultura patriótica: los Almacenes Rojas Hermanos vendían pisapapeles de cristal con la imagen de Simón Bolívar; pocos años después, pañuelos bordados con estampas ya no sólo del héroe nacional sino también del Ilustre Americano, del Capitolio y del Panteón. Y, cómo no popularizar la imaginería patria cuando Guzmán Blanco había puesto en marcha todo un programa de ornato público para embellecer los espacios caraqueños con estatuas de todos los insignes hombres de la nación.

En este sentido y sin restar importancia a otras manifestaciones culturales que se dieron durante el guzmanato con no poca intensidad -como los carnavales, los desfiles, las fiestas patrias, las apoteosis, los concursos literarios, los conciertos-, el carácter monumental de los edificios públicos y la estatuaria jugaron un papel preponderante tanto en el deseo de construir la memoria patrimonial de la nación, como el gesto más contundente de ordenar y disciplinar el espacio cívico. Y es aquí donde queremos remarcar una contigüidad sintomática entre el culto al personalismo de Guzmán Blanco y los próceres de la República con su mutua contaminación de reverencia y sacralización, y su objetivación en esculturas o pinturas de gran formato. La construcción del patrimonio nacional estuvo estrechamente vinculado con la preservación de la memoria del Padre, que se proyectó incólume a través de la piedra, del hierro, del bronce y del óleo, con una vocación hipertrofiada por sellar el carácter netamente androcéntrico de la agenda nacional y circunscribir el relato heroico de los tiempos fundacionales a una comunidad estrictamente masculina. ${ }^{6}$ No es casual entonces que conjuntamente con la preocupación por modernizar las infraestructuras urbanas jugaran un papel decisivo del nuevo orden citadino la construcción de plazas con sus respectivas estatuas; o más bien al revés, dentro de una gramática narcisista, el levantamiento de estatuas con o sin plazas.

\footnotetext{
${ }^{6}$ En este sentido, resulta de gran utilidad la revisión historiográfica que se está haciendo desde hace algunas décadas en vista de la recuperación de la "petite histoire” o "microhistoria”. Interesa para nuestro trabajo la diferencia conceptual establecida por el historiador Luis González al hablar de "historia matria", como aquella perspectiva de la investigación historiográfica que recupera todo lo soslayado por la historia patria, sinónimo de macrohistoria, historia oficial, varonil, "mundo del padre”. En contraposición, la "matria” (o la her-story) apuntaría al mundo pequeño, cotidiano, familiar, modesto, local, rutinario, intrascendente, menospreciado por la gran historia universal.
} 
Ya poco importaba la semejanza que se había establecido entre el Ilustre Americano y Simón Bolívar: a fin de cuentas si éste era el Padre, aquel "Regeneraba” la Patria. Guzmán Blanco logró armonizar ambos cultos: si bien ya desde 1874 inauguró la estatua ecuestre del Libertador en una Plaza Bolívar totalmente acondicionada para las retretas dominicales -monumento que habría de sobrevivir a los tiempos-, al año siguiente, los caraqueños tendrían que ver la erección de las estatuas del mismo Guzmán Blanco -“El Saludante” en 1875, y “Manganzón” en 1876- en lugares de obligado tránsito citadino: una frente al Palacio de la Exposición y la otra en El Calvario. Desde la colina, esta última dominaba con su desmesurada altura toda la ciudad: culto y control se maridaban emblemáticamente en la factura de la piedra, edulcorados por un paisaje de fuentes, jardines y cisnes, que no pudieron contener la furia iconoclasta de la oposición cuando decidió deponer las estatuas del presidente.

El culto personalista no debía sobrepasar al Padre de la Patria, lo que llevó también en el año del Centenario a decretar una gigantesca estatua de granito de Simón Bolívar de 18 metros para mitigar los desafectos al régimen. Las hipertrofiadas dimensiones del proyecto condujeron a su propia cancelación. No así la abrumadora ejecución de otras estatuas que completaron el ornato urbano de esa época: sólo en 1883 se colocaron los monumentos de Antonio Leocadio Guzmán en la plaza de San Jacinto; la estatua de Francisco de Miranda en el Panteón; de José María Vargas en el claustro universitario , y otra pedestre de Simón Bolívar en la fachada de la Universidad; de Juan Manuel Cajigal en el Colegio de Ingenieros; en la alameda de la iglesia de Santa Teresa el monumento a George Washington; y como su contrapartida , una estatua del Libertador en el Parque Central de Nueva York. ${ }^{7}$

La compulsión estatuaria no terminó aquí. Pero bástenos estos ejemplos para señalar que este gesto monumentalista decía del carácter de la agenda estatal, lo que implicaba un nuevo método pedagógico para disciplinar a las masas, suponiendo que éstas al entrar en la cuadrícula de la plaza transformarían sus pulsiones en un nuevo cuerpo civil que reconocería la estética del culto a los héroes, pero también la adhesión a los nuevos caudillos. Ingenuamente se creía que el orden y el progreso se iban a desprender por arte de magia de la piedra esculpida.

\footnotetext{
${ }^{7}$ La compulsión por el culto bolivariano no dejó de multiplicarse en versiones profanas y sacralizantes: desde alegorías y cuadros vivos, donde aparatosas utilerías ponían en marcha todo un escenario viviente para adorar al héroe nacional, hasta los enormes frescos y óleos que decoraban respectivamente el Salón Elíptico del Capitolio y las galerías del Palacio de la Exposición; desde pisapapeles, pañuelos, y fragancias, hasta himnos, odas y valses dedicados indistintamente al Padre como al Regenerador de la Patria. De este modo, el público podía ver tanto a su Padre patrio en las escenas de un pasado épico magnificado por la paleta de los artistas, como haberse impregnado el cuerpo con la misma agua de colonia que usaba el Libertador. Las tradiciones épicas de la historia nacional fueron construidas para el consumo de la gente, y de sagradas tenían muy poco. Efectivamente, las formas banalizadas fueron efímeras; las plasmadas en óleos y piedra formaron la memoria museológica del colectivo. Valga este anecdótico ejemplo: la gran pianista Teresa Carreño compuso para la memorable fecha un himno al Libertador. Sin embargo, el público la consagró como magistral intérprete de los maestros Beethoven, Chopin, Brahms, y Mozart.
} 
Pero no sólo de los mármoles y bronces de las estatuas, sino también de la monumentalidad de ciertos edificios públicos se decía del poder modernizador del Estado, de sus agentes, y de una nueva forma de empezar a recordar la historia. No en vano, siguen siendo puntos de referencia político-espaciales sensibles a la vida del país El Capitolio (1874), la Plaza Bolívar (remodelada en 1874), El Panteón (1875), el Paseo de El Calvario (1973), el Teatro Municipal (1881, antes Teatro Guzmán Blanco), el Cementerio General del Sur (1876), el Templo Masónico (1876), el Palacio de Justicia (1877), la Universidad transformada en el Palacio de la Exposición (entre 1873 y 1883).

Estos lugares de la memoria -que sin duda siguen llenando un espacio físico con capacidad aún de convocar rituales sociales-no sólo se conservaron, sino que configuraron desde aquel momento el sentido de un patrimonio nacional que el tiempo terminó por consagrar. ${ }^{8}$ Hasta aquí, tanto la escritura historiográfica como la misma dinámica de las prácticas institucionales ha preservado la memoria simbólica y material del monumento consustanciada con las materias "duras" de su factura, a despecho de haber subsistido en una sociedad con una memoria colectiva frágil y porosa que ha fagocitado hasta los bronces y los mármoles de sus hijos más preclaros. En todo caso, la obra de ingenieros y arquitectos, pintores y escultores, coreógrafos y diseñadores, poetas y letrados, quedó registrada en los anales de la ciudad letrada que protegió a sus criaturas viriles del olvido y del anonimato. Los Hurtado Manrique y Muñoz Tébar (responsables del Capitolio y del Palacio de la Exposición), los Arturo Michelena, Cristóbal Rojas, Martín Tovar y Tovar (responsables de los frescos de la "Batalla de Carabobo" y "La Firma del Acta de Independencia”), los Felipe Tejera, Eduardo Blanco (responsable de Venezuela heroica), los Adolfo Ernst (responsable de inscribir en la Historia la Exposición Nacional), nombres-canon, no sólo porque la tradición hegemónica patriarcal reprodujo en y a través de ellos sus marcas diferenciales de distinción, sino porque también las mismas instituciones (familiar y pedagógica) distribuyeron jerárquicamente los géneros de sus modalidades expresivas. ¿En qué lugar, entonces, quedaron los objetos “blandos” que fabricaron otras manos, o los lenguajes de otras voces menos fuertes?

LA GRAN ILUSIÓN: SE DEMOCRATIZAN LOS ESPACIOS

La Exposición Nacional de 1883 fue un momento fundacional para la creación de capitales simbólicos de la nación. Si bien legitimó una imaginería más sensible a los gustos

\footnotetext{
${ }^{8}$ El proceso de construcción de la memoria patrimonial del país ha sufrido en los 200 años de vida republicana fuertes embates y quiebres. Monumentos, esculturas, edificios, plazas, óleos, han sido objeto de escamotes, desplazamientos y destrucciones, que más bien has hecho hasta paradójicamente la formación de una tradición al respecto. Sin ir más lejos, ya la novela Ídolos Rotos (1901) de Manuel Díaz Rodríguez, a fines de la centuria problematiza la poca consistencia de los proyectos nacionales. El pueblo nunca vio presentadas sus necesidades en los intereses de la élite política; por ello sus esfinges, los "ídolos" de la oligarquía, son destruidos al final de la novela. También el Bolívar ecuestre de la plaza está cubierto de excremento de palomas. Los mármoles violados por la furia colectiva pone en tela de juicio el carácter "nacional” del proyecto modernizador. La memoria patriarcal que se ha querido construir ha sido doblemente falocrática: es la de un padre castrador de otras memorias y tradiciones.
} 
patriarcales dominantes, también fue cierto que abría sus puertas a una exhibición más democrática de los diversos sectores productivos del país. La fórmula del progreso reclamaba, al menos de fachada, la convivencia de cierta pluralidad y diversidad social, étnica y sexual en el espacio artificial de la Exhibición. Después de todo era una puesta en escena, una representación, una “presentación para”, que, como toda ficción, aunque no reflejase exactamente la realidad, no dejó de tener incidencias sobre la posterior transformación de las condiciones materiales de vida.

La convocatoria, realizada un año antes, no deseaba dejar ningún grupo social excluido; y tuvo al respecto un cuidado particular en invitar a que participasen con sus “obras y labores” las damas del bello sexo:

Notabilísimo éxito tuvo la idea del distinguido Presidente de la Junta Directiva, de pedir a las señoras Directoras de los Colegios nacionales de niñas por circular del 31 de enero de 1883, que presentasen en la Exposición obras de manos hechas por sus alumnas, no solamente como muestras de su habilidad e industria, sino también como un homenaje rendido por la inocencia infantil al Padre de la Patria (Ernst vol. III,17).

Incluir o no la participación de las mujeres venezolanas en la Exposición no debió ser un asunto fácil de dirimir, por cuanto que las deliberaciones del caso se tomaron varios meses: fue el último sector en ser convocado. Apenas el mismo año en curso del evento, meses antes, fueron invitadas. Sus respuestas por escrito a la Junta Directiva fueron lacónicas; apenas si agradecían el gesto; y sintomáticamente pasaron por alto tanto el hacer referencia al "Padre" como al "Regenerador" de la Patria. Prometieron organizarse y asistir.

Probablemente el cuerpo de ilustres varones que integraba la Junta Directiva de la organización del evento sopesó tendidamente exponer públicamente al “dulce ángel del hogar”, y de alguna forma comprometer peligrosamente los rígidos roles asignados a hombres y mujeres como también la rígida separación de espacios , más si tenemos en cuenta el carácter aún provinciano y conservador de las estructuras afectivas de la Venezuela finisecular, especialmente de la población masculina. Sin embargo, la situación ante el mundo ameritaba aparecer progresistas. Se había aprendido en otras Exposiciones Universales -a las cuales habían asistido delegados de Venezuela- que a las mujeres se les asignaba una sala; también a otros grupos "étnicos", como a los indios, negros del África, y asiáticos. ${ }^{9}$

\footnotetext{
${ }^{9}$ En las primeras Exposiciones Universales -Londres 1851, 1862; París 1855, 1867; Viena 1873; Filadelfia 1876- la participación de las mujeres fue aún tímida. Asistieron más mujeres de la localidad que invitadas extranjeras. Obviamente que las venezolanas brillaron por su ausencia hasta muy entrado el siglo xx. Sin embargo, es notable pensar en perspectiva que en la Exposición de Chicago de 1893 -a la cual fueron los escritores venezolanos Arístides Rojas y el mismo Adolfo Ernst y que reseñaron ampliamente el evento-, las mujeres consiguieron su propio pabellón, además diseñado por la arquitecta norteamericana Sophia Hayden, lo que significaba un enorme edificio para ellas. Del mismo modo, también en la Exposición de Filadelfia de 1876, ellas habían conseguido un pabellón propio, de dimensiones más modestas que la de Chicago. Ambos logros constituyeron un precedente significativo para la redefinición de la distribución sexuada de espacios y oficios. Los
} 
A la fecha prevista, la participación de las mujeres en la Exposición fue abrumadora en los renglones no sólo solicitados por ese ejecutivo, sino también en otros más cónsonos con los oficios desempeñados tradicionalmente por hombres: solamente en la sección relativa a "Bordados, encajes y pasamanería” fueron registradas por Adolfo Ernst 173 piezas, más de la mitad firmadas, y la otra, con firmas en representación de grupos colegiados. También en otras secciones su presencia no dejaba de asombrar: en los renglones de tapicería, alfombras, esteras, fibras textiles, tejidos, hamacas, cordelería, sombreros, floristería, confección de trajes para ambos sexos, corsés higiénicos, cacao, café, velas, jabones, pastas, alimentos envasados, y, muy particularmente, en la sección de "Trabajos en pelo" y "Flores y frutas artificiales de seda, carricillo, lana, plumas, cera, y etc.”, donde los organizadores habían agrupado las manifestaciones plásticas de las mujeres, obviamente no consideradas "artísticas”.

Aclaremos que el "etc.” del apartado debía incluir, por ejemplo, un "ramo de flores de escamas de pescado” de la señora Josefa Salias de Lugo, que tal vez a Adolfo Ernst le pareció excesivamente artesanal para tomarlo en cuenta en su catálogo, debiendo luego, y a pesar suyo, reconocerlo entre los premiados, así como tantos otros “trabajos” de mujeres que fueron reconocidos por el jurado de la Exposición: a título de ejemplo, fueron objeto de mención honorífica la tarjeta de raso de la señorita Natividad Rodríguez; un cuadro de ramillete de flores secas con migas de pan de la señorita María Isabel Cardoso; un escudo de Venezuela hecho con plumas de Mercedes Meneses; un pañuelo bordado con la Batalla de Carabobo de Isabel González Guinán; un cojín de retazos imitación mosaico de Felipa Geagan; el retrato del Libertador hecho con un marco de flores de cuero de Juana Bello, y el retrato bordado con pelo sobre gró del Ilustre Americano de la señora Josefa de Moreno Fernández. Estas últimas dos recibieron medallas de bronce, ya que, a despecho de haber sido confeccionados con materiales poco artísticos y nobles, el jurado quiso reconocer que fueron las únicas dos manifestaciones del sector femenino que aludían directamente a los homenajeados. Más les costó premiar a la señora Catalina Matute de Armas por su colección de dibujos de insectos, y a Dolores Ugarte (única mujer que pudo compartir la misma sala que los escultores) por su “Grupo de perros” hechos en barro. La señorita J. Paz Guevara con su retrato capilar de Policarpa Salavarrieta pasó inadvertida ante la mirada de los jueces.

A la Exposición Nacional concurrieron un total de 249 mujeres con identidad reconocida, rubricando con nombre y apellido sus objetos presentados. Pero estimamos que fueron más del doble de esta cifra ya que innumerables productos venían sin una identidad personalizada, simplemente como delegaciones oriundas de alguna localidad (por ejemplo, "Colección de Barquisimeto: tejidos de manta, de algodón, esteras, cocuizas, alpargatas, hamacas...) La cuestión del nombre no era simplemente un problema de firma; era la huella en la superficie de la lucha por la estabilización de identidades borradas del espacio público. Tanto la disolución de la identidad individual en esos colectivos sin rostro -cuerpos colegiados-, como la abrumadora presencia de autorías femeninas, revelaba en ambos casos una fuerza represada que, de algún modo, esperaba

amplios espacios de esos pabellones invitaban no sólo a exponer los habituales bordados, sino sus esculturas, pinturas y libros. 
la oportunidad para salir a la calle. La firma es ya el cuerpo presente de una identidad tomada; y el cuerpo colegiado su paso previo. Ambas modalidades son el envés y revés de la misma situación.

La cultura patriarcal de la República les había quitado el nombre, no sólo la identidad como ciudadanas, sino también la propiedad autoral con la que fabricaban cosas,

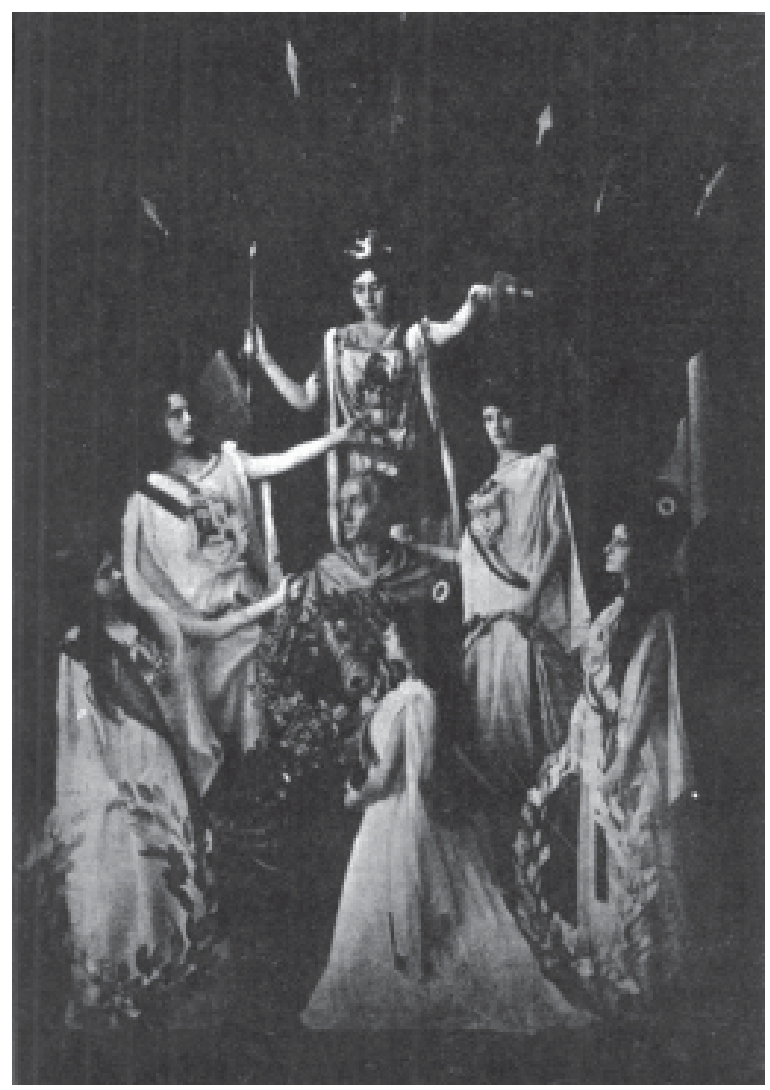

La cultura del guzmanato fue muy proclive-dentro del estilo grandilocuente e histriónico en boga- a los "cuadros vivos" o "alegorías fantásticas". Un gusto especial adquirieron las “Apoteosis del Libertador”. El año del Centenario (1883) la que más trascendió fue la realizada por Vicente Micolao Sierra y Felipe Esteves en el Teatro Guzmán Blanco (hoy Teatro Municipal). Los cuadros vivos eran alegorías de la nación, particularmente oportunas para la actuación pública de las mujeres sobre las tablas: era una manera "inteligente" de exponerlas fuera de la casa, pero convertidas en piezas simbólicas, petrificadas en atuendos grecolatinos, o fetiches satélites del Padre de la Patria. Era el guión ideal para evitar su movimiento y expresión. 
mercancías y artes. ${ }^{10}$ Pero es que también la cultura burguesa -en esos procesos de reacomodo jerárquico de las artes-había dis-locado la identidad artística de sus quehaceres reduciéndolos a artesanías en el mejor de los casos, y a "trabajos", en el peor de ellos. Había devaluado su competencia estética. Dejarlas sin nombre era operar en una doble dirección: por un lado, sacarlas del espacio público, quitarles la competencia de la palabra también pública (lo que implicaba quitarles el acceso a las letras), y, por otro, minimizar el complejo arte que practicaban (es decir, “menorizar” el tejido y el bordado). Por ello, la Exposición vino a significar una coyuntura muy oportuna para reestablecer en el espacio público la autoridad sobre las cosas que producían; y dentro de esa gramática, el sujeto viril tener que reconocer también públicamente lo que había desplazado. La nueva situación, precisamente por su fugacidad, no modificaba estructuralmente las condiciones básicas, pero re-colocaba a sujetos y prácticas en espacios im-pertinentes. En otras palabras, el sujeto masculino, que había reducido a la mujer a la casa con sus "labores de mano”, ahora estaba obligado a llamarlas para darles cabida en su territorio, y aún tener que reconocer sus méritos.

Las demandas políticas que implicaban las pretensiones cosmopolitas del gobierno guzmancista aceleraban -en un sentido positivo para el "bello sexo"- la democratización de la cultura visual a través de la Exposición, donde las mujeres pudieron efectivamente

\footnotetext{
${ }^{10}$ Ya en la Caracas de los años de 1837, el conocido Almacén de Modas de la señora Flandín, vendía toda clase de telas, vestidos y accesorios no sólo traídos de París, sino ya confeccionados en Venezuela; de igual modo, las señoritas Desiré Chillán, Anita Dupréz, Alejandra Manhaviale, entre muchas otras, regimentaban negocios en las calles de El Comercio y Leyes Patrias, que suministraban los más sofisticados atuendos, perfumes, zapatos y pelucas para satisfacer la coquetería de venezolanos y venezolanas. No sólo el nivel de consumo y de producción de artículos suntuarios -en buena parte en manos de modistas y negociantas- era elevado, sino que esto era indicador de una vida social intensa que invitaba a desarrollar las artes del baile, de la música, las tertulias, y el gusto por la lectura, a pesar de la inmensa precariedad de las infraestructuras urbanas. Así pues, cuando el Consejero Lisboa llegó a Venezuela en 1853, destacó en su relación de viaje la existencia de una extraordinaria pianista en Cumaná; así como su sorpresa por el opulento abastecimiento de mercancías en los almacenes de Caracas. Y en otro renglón que nos interesa, el Colegio de Educadas dirigido por las señoras Teresa y Concepción de Luque, llegaron en 1838 al próximo al ofrecer como premio 11 anillos con diamantes y dos con perlas a las más destacadas labores de bordado de sus alumnas. La entrega de los galardones se hizo en medio de una fiesta que contempló, además de un baile con banquete, la exposición en las galerías del instituto de las refinadas piezas bordadas. Por lo visto, el público estaba habituado a este tipo de eventos. Sin ir más lejos, y cerca de los predios de la Exposición Nacional, “El Café del Avila” organizó en 1872 la primera "Exposición de Pintura” en Caracas; allí apareció por primera vez la escultora Dolores Ugarte con su obra. Y no debió ser demasiado infrecuente el que las mujeres estuviesen públicamente involucradas con su arte. Por los años de 1877 tuvo relativo éxito comercial -porque hasta aviso tenía en La Opinión Nacional- la esposa de Manuel María Zarzamendi, que hacía por encargo "miniaturas de cromofotografía al óleo”. Y así suponemos que debieron existir no pocas mujeres pintoras, escultoras, músicas, que ofrecían sus servicios al mercado. Otra, por ejemplo, anunciaba también en La Opinión Nacional hacia 1884 que debía cerrar su taller y que remataba sus esculturas. El arte, sin duda, daba buenos dividendos; y probablemente muchas mujeres lograron su independencia económica gracias a la venta de su arte.
} 
entrar (o salir), pero circunscritas a una economía política no menos inclemente y llena de contradicciones. Significó un momento de flexibilización de las condiciones tradicionales. Podían decir que numéricamente eran una presencia y hasta una fuerza laboral no deleznable en la economía del país, sobre todo en lo tocante al área de los textiles y tejidos en general. ${ }^{11}$ En este sentido, el evento de la Exposición funcionó para ellas en dos direcciones cualitativamente opuestas, como dos fuerzas: una (centrípeta) que las incluía y resituaba; y, otra (centrífuga), que las volvía a excluir porque las reducía a artesanía y a la producción de objetos para el uso doméstico. ${ }^{12}$

La dinámica de las Exposiciones, en tanto uno de los espacios privilegiados de la sociedad de consumo, permitía -y hasta obligaba- aceptar a las mujeres como sujetos laborales que hacían cosas (y no arte), pero bajo unas reglas que simultáneamente las tornaba como instancias frágiles y evanescentes, con una existencia precaria, y con una historicidad volátil, como cualquier mercancía que se exhibe en la vitrina del mercado. Así pues, las condiciones de su ex-posición aparecieron doblemente efímeras, no sólo por el tipo de cosas a través de las cuales figuraron, sino porque además éstas estuvieron confeccionadas con materiales orgánicos perecederos. ¿Cómo preservar pelos, escamas, plumas, flores, hilos, estambres, migas de pan? Difícilmente ellas podían acceder al mármol o al bronce. Trabajaron con materiales que tenían a la mano; sacados de la cocina, de la naturaleza, de la quincallería. Tratadas como efemérides para la ocasión, llenaron los objetivos de pasar por objetos visuales indicadores del "progreso" nacional para el espectáculo no menos epidérmico de la modernización; pero, por el otro lado, pasaron a formar el paradójico "no texto" o vacío de la historia patrimonial (la historia del padre

\footnotetext{
${ }^{11}$ Es notable observar en el catálogo de Adolfo Ernst la cantidad de pequeñas industrias -si bien caseras- que estaban en manos de mujeres y que producían alfombras, hamacas, sombreros, guantes, alimentos, conservas, aceites, jabones, velas, tabaco, cacao, artículos de perfumería, fármacos, y en particular, fibras textiles y ropa. El mismo Adolfo Ernst no pudo dejar de reconocer a propósito de las mujeres de la Isla de Margarita "que produce un algodón de calidad superior, aunque no en abundancia. Se exporta poco, pues se utiliza en el país para hamacas, riendas, redes de pescar y otros artículos. Todo esto es obra de mujeres, y en efecto es cosa rara ver por allí una mujer ociosa” (3: 560). Esto nos hace suponer que muchas mujeres estaban al frente de importantes enclaves de la economía nacional, tanto en el agro como ya en el comercio, finanzas, hostelería, talleres tipográficos, fabricación de ropa, y, en el área de servicios, como modistas, costureras, peluqueras, maestras, institutrices, Después de las guerras de Independencia, el país laboral quedó diezmado, y las mujeres tuvieron que colocarse al frente de las propiedades y cubrir con su mano de obra la producción. El caso de la industria textil es revelador: en el catálogo se registraron como “delegaciones” por zona o como industrias propietarias de un hombre. Pero no sería desacertado pensar que la mano de obra la constituían contingentes de obreras.

${ }^{12}$ El "corsé higiénico" presentado por la señora Ana Aloe -quien fue premiada por tan útil confección- puede servirnos de ilustrativo ejemplo para calibrar cómo circulaban pendularmente los objetos de las mujeres en la dinámica de la Exposición. La prenda en sí hacía coexistir en ella, por un lado, toda la carga de la intimidad de lo privado. Allí figurativamente el cuerpo de la mujer estaba desnudado; por el otro, al ser expuesto públicamente y potencialmente serializado para el consumo, el encanto privado se diluía. Así, las categorías de público-privado se trastocaban en un vertiginoso trasvasamiento de superficies y fronteras.
} 
genera genéticamente vacíos con todo lo "blando”), es decir, de una historia “matria” sin memoria "textual”, es decir, sin soportes materiales.

Dentro de la cultura visual que sellaba la Exposición, el verdadero y quizás novedoso acontecimiento que ofrecían las salas del Palacio era el hecho de una presencia inusual de mujeres al evento. Adolfo Ernst, no menos asombrado ante este insólito hecho, comentaba en las primeras páginas de su catálogo que

Aquello fue una verdadera invasión de señoras, señoritas y caballeros, estando el bello sexo todo el día en constante y absoluta mayoría. Ni fue menos grande el concurso durante las horas de la noche, en las cuales todo el Palacio apareció espléndidamente iluminado con luz eléctrica, y lo mismo las avenidas del Capitolio y las Plazas Guzmán Blanco y Bolívar. (Ernst 3: 30)

En la dinámica de los acontecimientos oficiales ellas estaban de partida excluidas. Sabemos que no del panorama de la vida social de y para ese instante. El evento de la Exposición era su debut público en masa, y no tanto por el hecho de haberse presentado

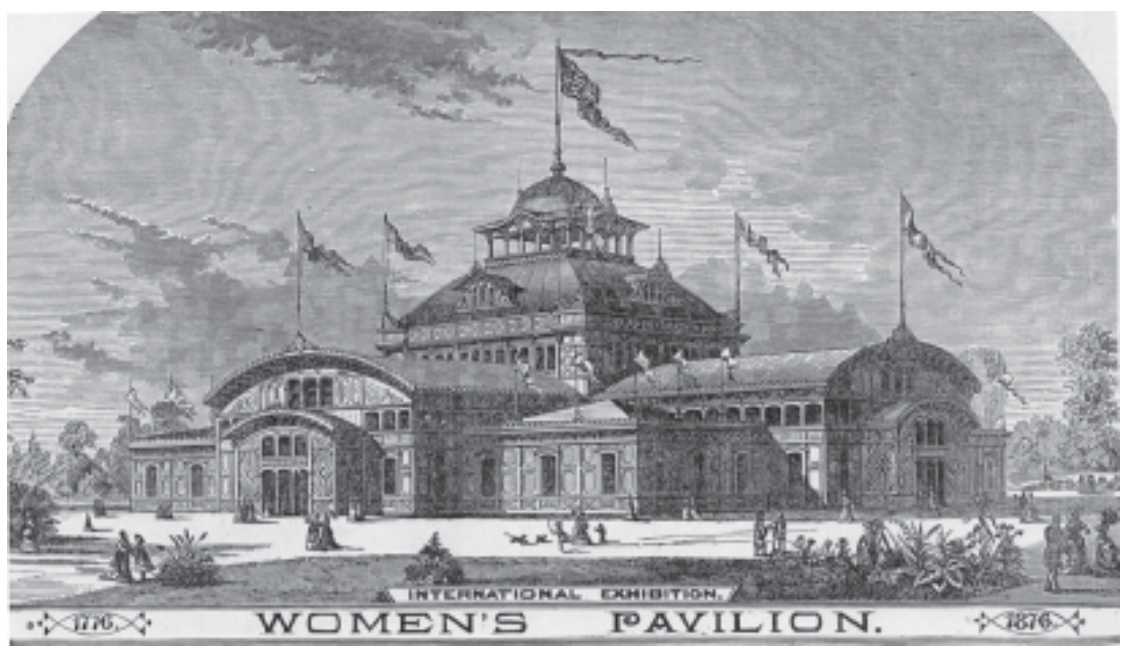

La Exposición Universal de Filadelfia se hizo para conmemorar el centenario de la independencia del país (1776-1876) Todas las Exposiciones aprovecharon fechas significativas para construir en un vertiginoso presente los pasados de la nación, así como también mostrar sus espacios socialmente plurales y multiétnicos. Las mujeres norteamericanas consiguieron en esa ocasión -y quizás era la primera en la historia de las Exposiciones- su propio pabellón. Posteriormente, como en la de Chicago (1893) su edificio sería mucho más grande.

con sus "labores de mano". Ya existía una tradición en el país donde las mismas mujeres organizaban ferias en bazares y colegios donde presentaban sus trabajos. Satisfacer la 
curiosidad y calmar la sorpresa, era ir a verlas a la Exposición. Ellas se convirtieron en su propio objeto de exhibición. Cual piezas de arte-no dejaban de ser el bello sexo-la mirada desplazaba su mecanismo de fetichización de sus objetos a la propia subjetividad de ellas.

Este complejo proceso de democratización de la mujer ayudó a desfigurar las fronteras nítidas entre la casa y la calle, entre el régimen doméstico y el mercado. A estas alturas, poco importaba si lo que se exhibía de ellas eran obras de arte o no; el gesto transgresor era colocarse a sí mismas en la mira, como sujetos aureáticos en la vitrina del consumo espectacular.

\section{PARADOJAS NEOGÓTICAS: LA PUNTADA SUBVERSIVA}

Volvamos una vez más al texto inicial de la convocatoria: en efecto, las mujeres podían presentarse, pero limitadas a sus “obras de manos”, para mostrar sólo su "habilidad” e "industria”. El sujeto femenino como realidad histórico-social quedaba fragmentado (de la totalidad del cuerpo, sólo las “manos”, y no la cabeza ni la lengua); la fuerza económica que potencialmente estaba significando se devaluaba (sólo "habilidades”, ni arte ni ingenio). Sus obras no pasaban de ser "labores”, "trabajos”, "artículos", “accesorios”, y , en el más desafortunado de los casos, cuando el lenguaje catalogar del historiador agotaba sus registros semánticos, pasaban a objetos "no clasificables". Probablemente a Adolfo Ernst, en más de una ocasión, le faltaron las palabras ante la inminencia del hecho femenino. Es decir, su competencia quedó reducida a "arte menor", que, como parte de la política del débil, les permitió explorar las infinitas posibilidades expresivas de materias sub y al-ternativas para las cuales el lenguaje institucional se revelaba incompetente.

Los límites del lenguaje de la escritura de la historia de la Exposición -la que ejerció Adolfo Ernst- entrañaba todos los matices tensionados entre el marco tradicional del nombrar y el des-centramiento de nuevos sujetos y situaciones. El ascenso cada vez más visible de las mujeres en áreas asignadas a los hombres produjo amenazas e inseguridades que motorizaron e intensificaron, por otro lado, toda una agenda de discursos que resolvían estos temores en una demonización o espiritualización de la mujer. Las representaciones oscilaron en esas décadas finiseculares entre su abyección o sublimación (vírgenes o putas, madres o ficheras, flores o serpientes). ${ }^{13}$ Mientras tanto, el índice de

\footnotetext{
${ }^{13}$ Acudieron a la Exposición Nacional un buen número de óleos de pintores venezolanos que ofrecieron en la sala de "Bellas Artes” una galería de cuadros que resolvían para la ocasión escenas de la historia épica nacional. Entre el "Juramento de la Independencia" de Martín Tovar y Tovar, "La Muerte de Guaicaipuro" de Manuel Cruz, el "Incendio en el Parque de San Mateo” de Antonio Herrera Toro, "La Muerte de Girardot” de Cristóbal Rojas, la "Entrevista de Bolívar y Sucre en el Desaguadero de los Andes” de Manuel Otero, la "Batalla de Carabobo" y “El Desembarco de Bolívar en Ocumare" de Arturo Michelena, entre varios más, también fueron expuestos de los mismos autores cuadros con figuras femeninas. Es interesante ver cómo en estos casos la mujer fue representada en versiones alegorizadas (como la "Alegoría de Bolívar y las cinco Repúblicas" de Manuel Cruz), o en versiones espiritualizadas (como la "Margarita de Fausto" de Emilio Mauri, y la "Cabeza de una Madona” de Antonio Herrera Toro), o reducida a puro cuerpo (como el "Desnudo" de Pedro Emilio Rodríguez Flegel). La otra mujer, la mujer real de su presente histórico que tenían
} 
mujeres alfabetizadas en Venezuela durante el guzmanato superó con creces a la población masculina: la mujer no sólo era la que más leía, quizás más música tocaba, y probablemente escribía mucho más. ${ }^{14}$

El repliegue misógino del hombre de letras habilitaba su ceguera para visualizar el sujeto femenino real. Y el acontecimiento de la Exposición operó en sí como un texto que nombraba a la mujer desde parámetros, que, si bien la "nombraban”, la disciplinaban otra vez en el orden del discurso patriarcal. Y, en este sentido, el diseño neogótico del Palacio no fue simplemente una formalidad arquitectónica con los tiempos modernos; expresaba

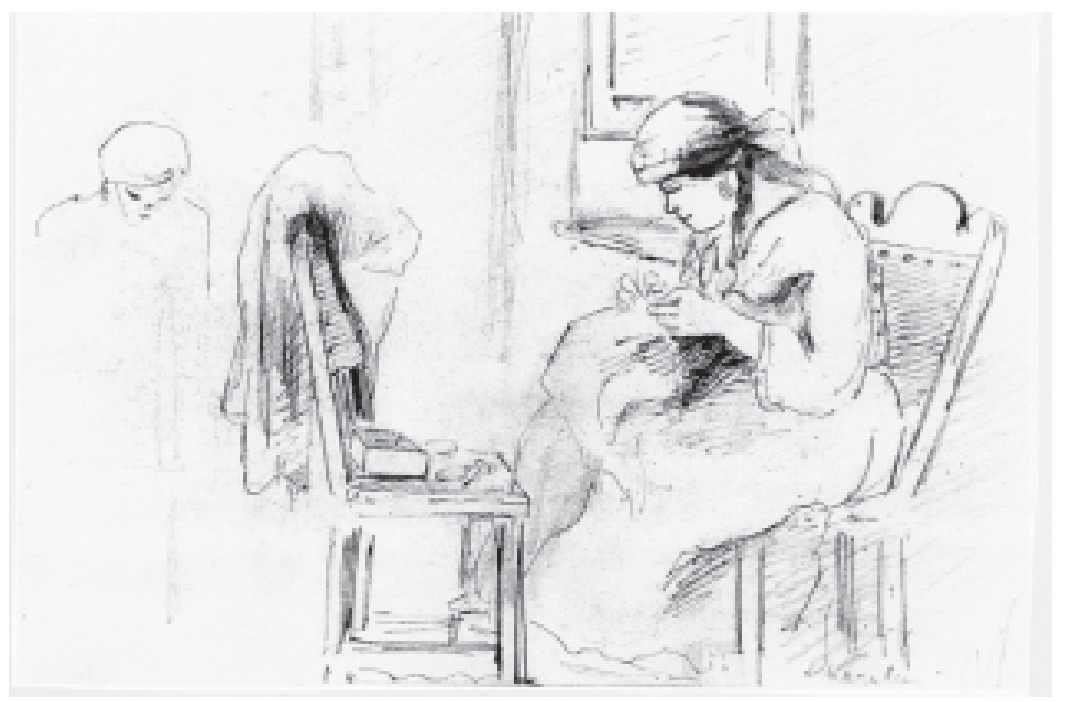

Muchos viajeros visitaron a Venezuela durante el siglo xix. Sus relatos así como sus dibujos constituyen una rica cantera de información. Entre ellos, el pintor francés Camille Pizarro recorrió a mediados del siglo el país. En carboncillo, un boceto de "Dos mujeres cosiendo en un interior” (1853). Debemos suponer que la costurera era uno de los oficios más frecuentes entre las mujeres; y para que el pintor las hubiese registrado, no debieron ser pocas. La fuerza laboral femenina hallaba en los textiles una de las fuentes más rentables de ingreso económico, pero también una de las formas de organización social que podía viabilizar la formación de otra conciencia de sí mismas.

allí delante, como la escultora Dolores Ugarte, o la pintora belga Fany Laumans, o las centenares de mujeres de las salas contiguas, se les escapaba en el ángulo ciego de su propia visión.

${ }^{14}$ En 1872, en la ciudad de Caracas, Isabel Alderson emprendió como directora de la revista Ensayo Literario una no corta carrera como directora de esa publicación. Entre dos intensos años sacó más de 78 números. Escribía los artículos, hacía traducciones, llevaba el canje, la publicidad, las ventas, las suscripciones. Y bajo algún seudónimo, también se animó a publicar novelas en los espacios de su propia revista. 
en otros niveles también las contradicciones de esa modernidad, que lidiaba simultáneamente con aperturas democratizantes, pero celando no perder antiguas estructuras señoriales de poder. Del mismo modo, la canalización de la participación de las mujeres, principalmente a través de sus "labores de mano", reforzaba en el territorio público su lugar en el espacio doméstico: el telar, el bordado, la costura, eran oficios de la casa, ceñidamente constitutivos de la feminidad. Más: tejer y bordar eran actividades que agrupaban a las mujeres en fraternidades regidas bajo el silencio monacal. El estilo neogótico del Palacio sin duda complacía albergar a mujeres que reforzaban con su quehacer una larga tradición medieval... El ascenso de los sectores medios -y entre ellos también ascendió al escenario de la Exposición la humilde costurerita-no necesariamente significaba la masificación de los gustos populares. Una nostalgia por ciertos estilos aristocratizantes se imponía entre las masas. La visibilidad que ocupó el bordado se conjugaba con el aire caballeresco de las ojivas del Palacio.

Por consiguiente, la cultura patriarcal -y no en menor grado el Consejo Directivo que organizó la Exposición- tenía muy en alto estas labores del bello sexo, porque , al valorar el tejido, controlaba la palabra de las mujeres. Al asignarles un espacio preponderante en la Exposición, se les estaba en verdad re-evaluando su lugar estratégico en la casa, y promoviendo el modelo ideal de mujer adscrito al lenguaje del tejido y del silencio. La apertura democrática era un terreno resbaladizo y tramposo a la vez. Al exhibirse podían volver a asimilar los roles de obediencia y sumisión que entrañaba el bordado. Celebrarlas en sus oficios era mantenerlas a raya y evitar que asaltaran las "artes mayores", en particular la literatura, de la cual fueron elegantemente excluidas: en la sección de "Obras científicas, literarias y musicales” los consagrados fueron los padres de las letras nacionales. Allí se empezó a decidir el canon literario fundacional: figuraron Eduardo Blanco con su Venezuela Heroica; Felipe Tejera con La Bolíviada, La Colombíada, y Triunfar con la Patria; Ramón de la Plaza con el Ensayo sobre el arte en Venezuela; Arístides Rojas con los Orígenes de la Revolución venezolana; y Hortensio con sus dos tomos de Literatura venezolana. Los dueños de la palabra escrita configuraban otra comunidad aparte: la letra era ejercida con el mismo gesto heroico que las armas. Escribir era una cuestión pública y con ella se ejercía el poder de fabricar invenciones historiográficas.

Pero las trampas de la democratización no sólo operaron favorablemente para los que controlaban el poder de los lenguajes interpretativos. El silencio de la mujer que bordaba inquiría ser quebrado; esperaba ser interrogado para poder hablar. Pero como no debía ser interrumpido - de la laboriosidad dependía su virtud-, hablaba entonces por el lenguaje de los hilos. Sus tejidos hablaban por ellas. Y con hilos de oro y plata; y géneros de seda, raso, terciopelo, lana y algodón; y materias como pelos, escamas, trigo y migas de pan, se presentaron a la Exposición apropiándose de la agenda patriótica. El tema político era una arena en principio vedada para ellas; sin embargo, la ocasión facilitaba hacer su propia incursión en el asunto. Después de todo no podían dejar de ser también buenas ciudadanas.

En el campo de las representaciones verbo-simbólicas la tendencia general -como expresión de las hegemonías- giró compulsivamente entorno a Simón Bolívar, a los héroes de la Independencia, y consecuentemente, alrededor de Guzmán Blanco. Sobraron motivos patrióticos donde los artistas aprovecharon para darles rostro a todos los protagonistas pasados y presentes de la nación. A ratos la fisionomía de Guzmán Blanco 
se mimetizaba con la del Libertador. A contrapelo de esta inundación de "bolívares” y “guzmanes”, aquellas mujeres, que se habían aventurado con sus bordados y cuadros de pelo a tocar temas patrios, decidieron -salvo en dos casos- eludir la representación de ambos Padres de la Patria. Al parecer,

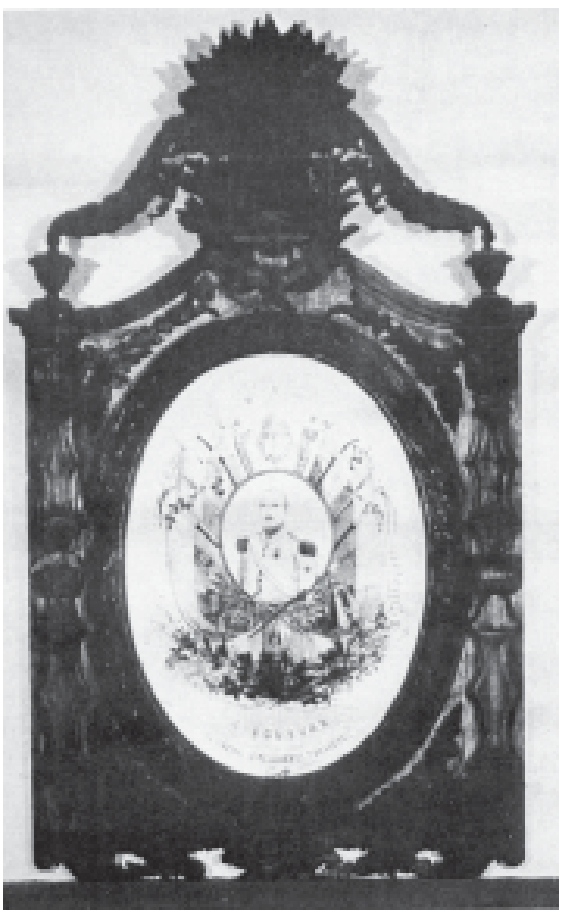

Entre las decenas de obras presentadas por mujeres en la Exposición Nacional -algunos retratos hechos a base de pelo como éste- no se conservó ninguna. Por tratarse de mujeres, no se consideraban obras de arte en sí. Sin embargo, el Retrato del General Juan José Flores (1883) realizado por Faustino Padrón, también hecho a base de cabellos del prócer, aún puede ser Entendemos que los cuadros bordados con pelo tuvieron aproximadamente esta factura. Por extensión, podemos inferir que el retrato de Policarpa Salavarrieta hecho por la señorita J. Paz Guevara era similar a éste conservado. apreciado en la colección del Museo Bolivariano. otra figura masculina les parecía de mayor mérito: hubo dos obras que retrataron a otro general, a Roberto Ibarra. Los demás trabajos optaron por motivos alegóricos, donde su compromiso con las ofertas de temas políticos disponibles se resolvía en un discreto abstraccionismo que les permitía cómodamente insertarse en la cuestión nacional, pero sin manifestar mayor adhesión a la autocracia guzmancista como tampoco al culto bolivariano.

Sus trabajos oscilaron entre la representación del escudo de Venezuela, la alegorización de las cinco repúblicas liberadas por Bolívar (lo que daba cabida a trabajar con figuras femeninas), la Batalla de Carabobo, y motivos masónicos. Sin ninguna pretensión de grandilocuencia y menos de trascendencia histórica, estos motivos decoraban, por ejemplo, pañuelos, mantillas, reclinatorios; inclusive una llegó a bordar una colección de alpargatas cada una con los respectivos escudos de las naciones bolivarianas. Independientemente de la posible disonancia (o gusto kitsch) que se pueda encontrar en estas manifestaciones, donde los elementos del "high style" convivieron con un "popular style", nos interesa poner de relieve su elipsis con respecto a los motivos centrales del Centenario. Probablemente que la preferencia por una interpretación alegórica de la nación podía decir muchas cosas, entre ellas, su no plena y mecánica identificación con los imaginarios viriles de la nación. El carácter despersonalizado de las alegorías tal vez les daba un márgen para reelaborar la nación a su modo. Ellas habían estado involucradas en el curso de los acontecimientos históricos y no como meras espectadoras. Fueron un engranaje clave en 
las situaciones de guerra, y piezas indispensables en tiempos de paz: ¿si no, cómo entender su apropiación de la mitra masónica ${ }^{15}$ Los bordados revelaban claves secretas, saberes precisamente no domésticos, y podían dar pistas de sus recorridos clandestinos.

Y allí estaba el retrato de Policarpa Salavarrieta. Volvamos de nuevo a su inquietante presencia, punto desestabilizador ante tantas virilidades heroicas. Como un monolito solitario dentro de las masculinidades patrióticas serializadas, cobraba una dimensión significativa que traspasaba los inocuos límites del retrato. En manos de la señorita J. Paz Guevara -que le había bordado el rostro tal vez con su propio cabello-, Policarpa emergía en el espacio de aquella Exposición con la ambivalencia de su doble identidad.

Simbólicamente podía extender su mirada hacia las mujeres que trabajaban -como también ella lo había hecho- como costureras para ganarse la vida. Allí su empatía con el arte de las labores de mano, los hilos, las telas, los textiles; también el trabajo de puertas adentro, el silencio, la sumisión, la máxima virtud. Pero este guión también podía significar la mujer que se ganaba la vida con un trabajo “doméstico”, facilitándole cierta independencia económica.

Sin embargo, y por el otro lado, este ángulo de la colombiana permitía la identificación del trabajo aparentemente insignificante de miles de costureras con la heroína, porque en esa actividad silenciosa que des-identificaba a la mujer o la diluía en una espiritualidad pre-feudal, le había permitido a Policarpa Salavarrieta desempeñarse como ágil espía al servicio de la causa patriótica: mientras cosía en las casas del enemigo, camuflada como simple costurera, obtenía valiosas informaciones para los compañeros de lucha. En su doble identidad -como costurera y revolucionaria- se apropiaba de un saber que iba tejiendo en finas redes informáticas. Al tiempo que los hilos empalmaban tejidos de diversa textura, del mismo modo su trajinar sigiloso por veredas y poblados tejía otras superficies que permitían movilizaciones nomádicas libertarias. La costura le había enseñado que miles de puntadas invisibles transformaban el lenguaje de las telas; también del mismo modo, llevar y traer las claves de un saber secreto iba tejiendo redes que configurarían otras realidades históricas. Su saber y riesgo eran decisivos para la libertad de la Patria.

El silencio, la falsa identidad, el trabajo imperceptible e implacable, el cauteloso ir y venir como el huso del telar , fueron elaborando a lo largo de sus 24 años un texto cuyo tramado no estuvo hecho con el lenguaje de la palabra escrita, sino con las voces amortiguadas y clandestinas de la memoria oral. Permanecer en silencio no significaba necesariamente no decir nada; podía significar el tramado de una peligrosa (in)subordi-

\footnotetext{
${ }^{15}$ Los tiempos contemporáneos son particularmente sensibles a denunciar a través del testimonio las torturas y desaparecidos de los regímenes de fuerza. Sin embargo, fueron centenares las mujeres, para el caso, que durante las guerras de Independencia fueron torturadas, vejadas, descuartizadas públicamente. Repasemos sólo algunos pocos nombres en Venezuela: Josefa Joaquina Sánchez Bastidas (esposa de José María España), Josefa Palacios (esposa de José Felix Ribas), Nicolasa Briceño, Josefa Camejo, Dominga Ortíz de Páez (enfermera de los ejércitos patriotas y esposa de Páez), Concepción Mariño, Luisa Cáceres de Arismendi, Mariquita Figueras: todas mujeres cuyos maridos pasaron a la historia, mientras ellas pasaron largos años de prisión, bajo régimen de torturas, y luego la muerte.
} 
nación, donde la casa por cárcel podía ser el lugar más imprevisible de alteración del orden público.

Policarpa Salavarrieta fue fusilada en 1817. Su última comunión la transformó, ante el desconcierto y alarma de las autoridades virreinales, en una arenga revolucionaria. El pueblo que la había acompañado recordaba esas sus últimas palabras.

El pelo con el que estuvo bordado su rostro en el cuadro de la Exposición fue un homenaje de las mujeres

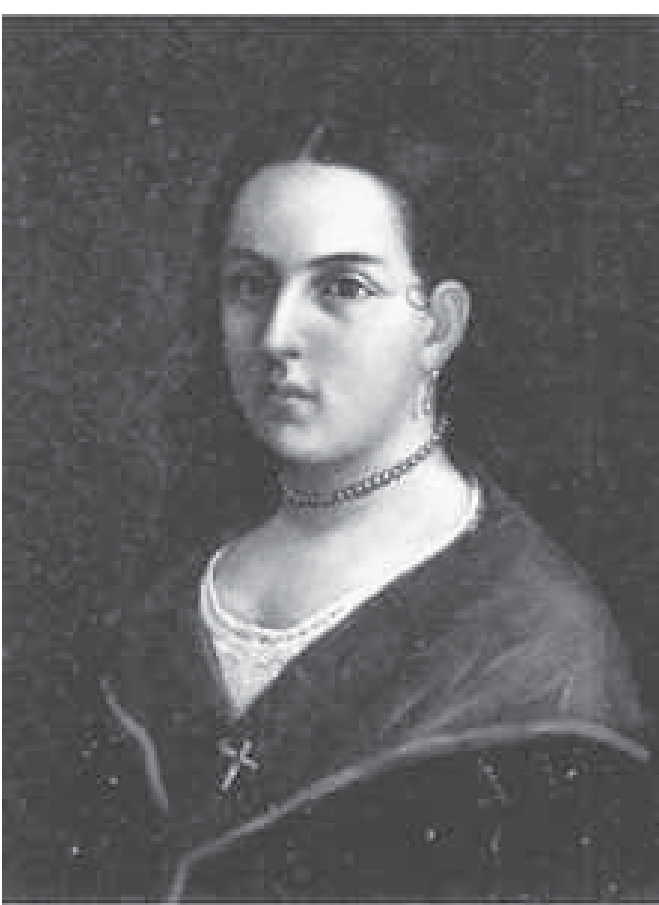

Retrato al óleo de Policarpa Salavarrieta (17931817) de José María Espinosa pintado a mediados del siglo. Fue una de las tantas mujeres que participó activamente en los procesos revolucionarios de la Independencia. Su actividad política le costó la vida. Tal vez por el modo cómo fue fusilada, el recuerdo de Policarpa sobrevivió en la imaginación popular a través de poemas y canciones. Algunos dramaturgos (como el venezolano Heraclio Martín de la Guardia y Lisandro Ruedas) se inspiraron en la biografía de la colombiana para escribir sus obras dramáticas. Su recuerdo no ocupó un lugar visible en la memoria oficial. Serán los sectores subalternos -pueblo, mujeres, y literatos de tercera- que la van a convertir en un punto de referencia de otra memoria. venezolanas a su propia otra representación posible. Allí, las implicaciones de Policarpa dejaban colar una ranura a través de la cual re-direccionar la disatisfacción con el lugar "casero" e incontaminado que se les había asignado. A través de los ojos de Policarpa las mujeres de ese fin de siglo podían mirar(se) con nostalgia a un pasado donde aún podían transitar de la casa a la calle, y ser protagonistas en el terreno político. Obviamente que en la medida que la República afinaba sus premisas, iba limitando oficialmente la circulación de la mujer: los tiempos modernos no necesariamente eran más progresistas. El cuadro de Policarpa tejía un puente silencioso entre las mujeres de 1883 y los momentos fundacionales de la nación.

Como las dos caras de las telas bordadas, era una obra en clave. Podía tener una doble lectura: era un homenaje a las costureras, a las trabajadoras de los secretos del "arte menor"; pero al tiempo les daba las pistas de un ejercicio subvertidor, porque con las miles de puntadas podían estar vertebrado otros saberes y otras batallas. Su lucha por el poder 
interpretativo de los signos debía ser un arte discreto y sin escándalo. No en balde, la señora Isabel González Guinán había bordado en uno de los pañuelos “La Batalla de Carabobo”. Arriesgando sobreinterpertaciones, nos gustaría pensar que la batalla de Isabel en su pañuelo tenía simbólicamente otras implicaciones. Lamentablemente el repertorio temático con el que las mujeres podían representar su mundo estaba cultural e históricamente pautado. Salirse de él, si no impensable, era arriesgar la carta de buena ciudadanía y exponerse a la desfiguración pública.

Sin embargo, y como contrapunto complementario a la placidez inofensiva del retrato de J. Paz Guevara, en un rincón de la sala destinada a las artes plásticas colocaron la escultura de barro de la venezolana Dolores Ugarte. Recordemos que se trataba de unos perros. ¿Qué podían hacer allí unos perros hechos además de barro junto al óleo de 6 metros de "El Juramento de la Independencia” de Martín Tovar y Tovar? La convivencia de ambas obras en el mismo espacio, aparte de decidir el destino injusto de la escultora, contaminaba y redefinía de sentidos a ambos trabajos. El cuadro de Tovar y Tovar consagraba el agenciamiento de comunidades viriles en asuntos intelectuales y estatales, configurando un cuerpo compacto de puros hombres para evitar la filtración femenina. De algún modo, Dolores Ugarte estaba siendo violentamente marginada no sólo en cuanto al lugar físico que ocupaba en la sala, de los espacios simbólicos de representación (como sujeto femenino tanto en el sentido de la Vertretung como de la Darstellung), sino, además y finalmente, también del catálogo de Adolfo Ernst, que llanamente no había considerado significante nombrarla.

La violencia de la múltiple exclusión operaba metafóricamente a través del motivo prosaico y hasta disonante de ese conjunto de perros. Aquí los “perros” también permiten varias lecturas: señalaban de otro modo esas comunidades viriles -en verdad marciales y bélicas- que se agredían desgarrándose unos a otros en nombre de la Patria; también motivo prosaico, casi tomado de la vida (intranscendente y cotidiano), decía de la identidad real del sujeto femenino que había elaborado la obra. Identidad real y disgustada. Es decir, los perros hacían un llamado de atención hacia la representación históricomaterial de la mujer, lejos de su fetichización como virgen o demonio. El barro con el que estaban confeccionados apelaba a una resemantización de su lugar en la vida social.

La violencia de los perros apuntaba en varias direcciones. Dolores Ugarte menos discreta, decidía hablar con mayor franqueza a través del lenguaje de las formas poco galantes. Su distancia y disidencia de todos los códigos estéticos ofertados le costó el recuerdo.

La Exposición Nacional de 1883 creó un espacio histórico para la negociación no sólo de la representación de la mujer, sino de su efectiva participación. No modificó sustancialmente sus condiciones de inserción social. No cambió su lugar en el recinto doméstico. Pero sí configuró un marco a partir del cual repensar la problemática del género sexuado en su conjunto. Para las mujeres la Exposición fue un acto político que les permitió repensarse y pensarse dentro de la nación. Les dio de alguna forma voz, aun cuando ésta estuvo expresada a través del barro o de los hilos y agujas. Fuera de la ciudad letrada usaron su propio lenguaje y no es otra que la cárcel del lenguaje verbal (y su consecuente el literario) que impide y ha impedido ver otros signos y texturas donde las mujeres han dejado inscritas la líneas de su propia historia. 


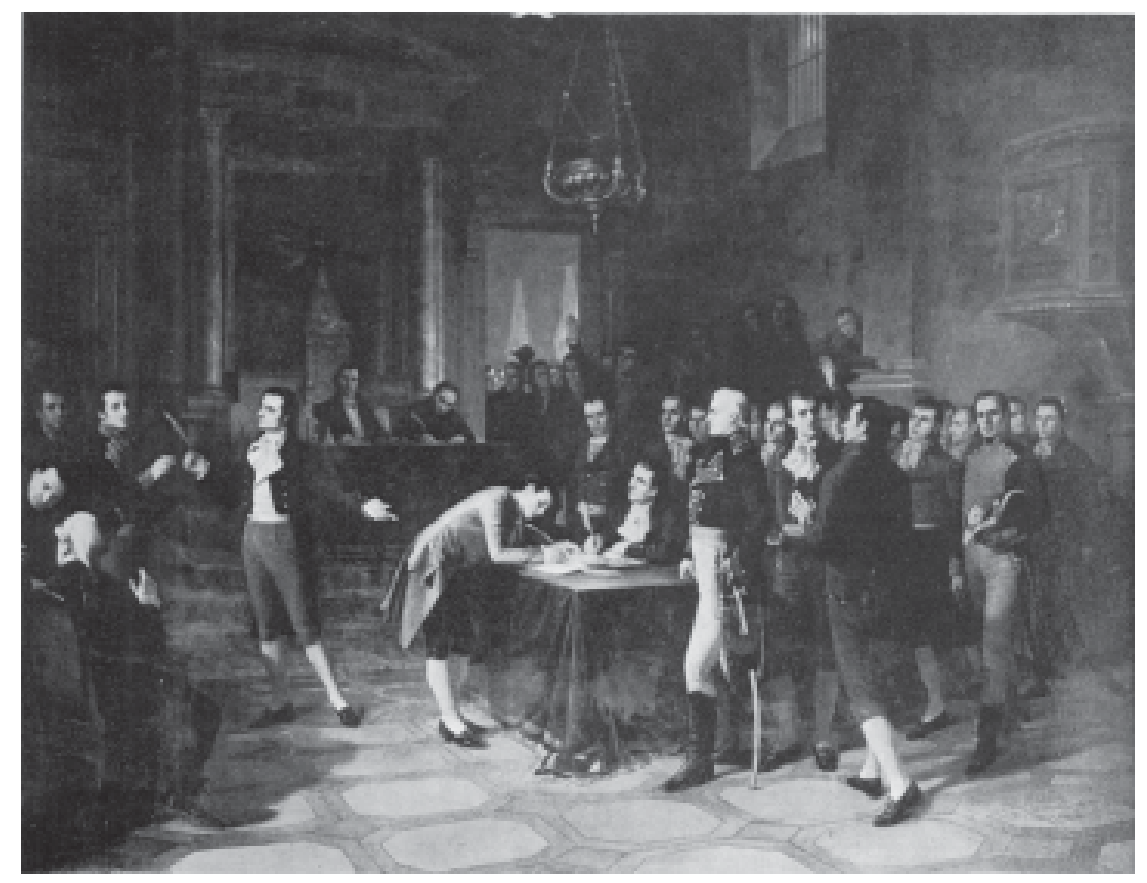

"La firma del Acta de la Independencia” de Martín Tovar y Tovar ocupó uno de los lugares centrales en la Exposición Nacional. Recibió además el premio principal. Resumía para la época no sólo una representación satisfactoria del cuerpo de hombres ilustres que fundaron la patria, sino también decía del pacto presente que debían suscribir los hombres públicos en tanto comunidades viriles para decidir los asuntos estatales. A manera de una cofradía, firmaban simbólicamente el cierre de sus filas para impedir la entrada de cualquier sujeto social que no fuese blanco y masculino. Significativamente este óleo pasó a formar parte del museo de Bellas Artes, y es uno de los baluartes señeros del patrimonio nacional.

\section{BibLIOGRAFÍA}

Appadurai, Arjun(ed.). La vida social de las cosas. Perspectiva cultural de las mercancías. México: Grijalbo, 1991.

Auge, Marc. Las formas del olvido. Barcelona: Gedisa, 1998.

Barthes, Roland. Image, Music, Text. Nueva York: Hill and Wang, 1999.

Bourdieu, Pierre. La distinción. Criterio y bases sociales del gusto. Madrid: Taurus, 1988.

Brunet, Marta. “Soledad de Sangre”. Soledad de Sangre. Montevideo: Arca, 1967.

Cao, Marián L.F. (coord.). Creación artística y mujeres. Recuperar la memoria. Madrid: Narcea, 2000. 
Castiglione, Dario y Lesley Sharpe (eds.). Shifting the Boundaries. Transformation of the Languages of Public and Private in the Eighteenth Century. Inglaterra: University of Exeter Press, 1995.

Cordato, Mary Frances. "Representing the Expansion of Woman’s Sphere: Women’s Work and cultural at the World's Fair of 1876, 1893, and 1904”. Tesis Doctoral: New York University, 1989.

Cherry, Deborah. Beyond the Frame. Feminism and the Visual Culture, Britain 18501900. Londres: Routledge University Press, 2000.

De Diego, Estrella. La mujer y la pintura del XIX español. Madrid: Cátedra, 1987.

Debord, Guy. The Society of Spectacle. Nueva York: Zone Books, 1994.

Díaz Rodríguez, Manuel. Ídolos rotos. París: Imp. Española de Garnier Hermanos, 1901.

Ernst, Adolfo. La Exposición Nacional de Venezuela en 1883, Obras Completas. Vols. 3 y 4. Caracas: Fundación Venezolana para la Salud y la Educación, 1983.

Esteva Grillet, Roldán. Guzmán Blanco y el arte venezolano. Caracas: Academia Nacional de la Historia, El libro menor, 1986.

González, Luis. Otra invitación a la microhistoria. México: Fondo de Cultura Económica, 1997.

Grant Darney, Virginia. “Women and World’s Fairs: American International Expositions, 1876-1904”. Tesis Doctoral: Emory University, 1982,

Greenhalgh, Paul. Ephemeral Vistas. The Expositions Universelles, Great Exhibitions and World's Fair, 185l-1939. Nueva York: Manchester, 1988.

Harris, Neil et al. Grand Illusions Chicago's World's Fair of 1893. Chicago: Chicago Historical Society, 1993.

Hearman, E.A. The Inglorious Arts of Peace. Exhibitions in Canadian Society during the Nineteenth Century. Toronto: University of Toronto Press, 1999.

Higonnet, Anne. "Secluded Vision. Images of Femenine Experience in NineteenthCentury Europe”. The Expanding Discourse. Norma Broude y Mary D. Garrard, eds. Boulder, CO: Westview, 1992.

Hunt, Lynn. Politics, Culture, and Class in the French Revolution. Berkeley: University of California Press, 1984.

Karp, Ivan y Steven D. Lavine (eds.). Exhibiting Cultures. The Poetics and Politics of Museum Display. Washigton: Smithsonian Institution, 1991.

La Mujer en la Historia de América. Tomo I Caracas: Asociación Civil. La Mujer y el V Centenario de América y Venezuela, 1995.

Lamas, Marta (comp.). El género: la construcción cultural de la diferencia sexual. México: UNAM-Porrúa, 1996.

Landes, Joan B. Women and the Public Sphere in the Age of the French Revolution. Ithaca/ Londres: Cornell University Press, 1988.

Lisboa, Consejero Miguel María. Relación de un viaje a Venezuela, Nueva Granada y Ecuador. Caracas: Fundación de Promoción Cultural de Venezuela, 1986.

Lowenthal, D. The Past is a Foreign Country. Cambridge: Cambridge University, 1985. Majluf, Natalia. Escultura y espacio público. Lima: 1995.

Nochlin, Linda. Women, Art and Power and other essays. Nueva York: Harper \& Row, 1971. 
Parker, Rozsika. The Subversive Stitch. Embroidery and the making of the femenine. Londres: The Women's Press Limited, 1984.

Plaza, Ramón de la. Ensayos sobre el arte en Venezuela. Caracas: Imprenta de "La Opinión Nacional”, 1983.

Pollock, Gisele. Vision and Difference. Feminity, Feminism and the Histories of Art. Londes/ Nueva York: Routledge University Press, 1988.

Rojas, Arístides y Adolfo Ernst. Exposición Universal Colombiana de Chicago (catálogo). Venezuela/Nueva York: Gobierno de Venezuela, 1893.

Salas, Horacio. El Centenario. La Argentina en su hora más gloriosa. Argentina: Planeta, 1996.

Silva Beauregard, Paulette. Una vasta morada de enmascarados. Caracas: Fundación La Casa de Bello, 1993.

Stevens Carl, James. Victorian Architecture. Londres: David \& Charles, 1990. Venezuela 1883. 3 Tomos. Caracas: Ediciones del Congreso de la República, 1983.

Weimann, Jeanne M. The Fair Women. Chicago: Academy Chicago, 1981. 